\title{
PRELIMINARY RESULTS OF MAPPING IN THE CRYSTAL- LINE COMPLEX OF RENLAND, THE SOUTHERN STAUN- ING ALPER AND SOUTH-WEST LIVERPOOL LAND, SCORESBY SUND, EAST GREENLAND
}

\author{
Niels Henriksen and A. K. Higgins
}

\section{Introduction}

The Caledonian crystalline complex of Renland and the southern Stauning Alper, south and north of the outer part of Nordvestfjord, was mapped by GGU (Grønlands Geologiske Undersøgelse) on a 1:50 000 scale in the summer of 1969. The region to the west, around the inner part of Nordvestfjord, was mapped in 1968 (Henriksen \& Higgins, 1969). To the east the crystalline complex is bordered by prominent faults which separate it from the Upper Palaeozoic and Mesozoic rocks of the Jameson Land basin.

The mapping around outer Nordvestfjord was carried out by the following geologists: B. Chadwick, Exeter; J. D. Friderichsen, Copenhagen; N. Henriksen, Copenhagen; A. K. Higgins, Copenhagen; F. Keller, Zürich; H. Rutishauser, Bern and $\mathrm{A}$. Steck, Basle. The areas mapped by each geologist are indicated on the index map of map 1.

Mapping was also undertaken in south-west Liverpool Land, along the east side of Hurry Fjord. R. F. Cheeney, Edinburgh, mapped the southern part of this area, and $\mathrm{K}$. Coe, Exeter, mapped the northern part. A brief report on the work in Liverpool Land is given towards the end of this paper.

Very detailed maps of small areas of migmatites on the Bjørneøer were made by R. H. Steiger, Zürich, in cooperation with $F$. Oberli, Zürich, in connection with special geochronological investigations. The results of this work will be published in due course.

The mapping was mainly of a reconnaissance nature in that each geologist was expected to cover an area of $500-1000 \mathrm{~km}^{2}$ during a six week field season. The mapping was also a team project. In preparing this preliminary report the writers have made considerable use of ideas and views expressed by the other participants in reports and field maps, for which they acknowledge their gratitude. However, this does not mean that all members of the team agree with the interpretation the writers have made based on their results. In the coming years most of the participants will publish detailed accounts of their individual areas, and geological map sheets on a scale of $1: 100000$ will be published by GGU. 


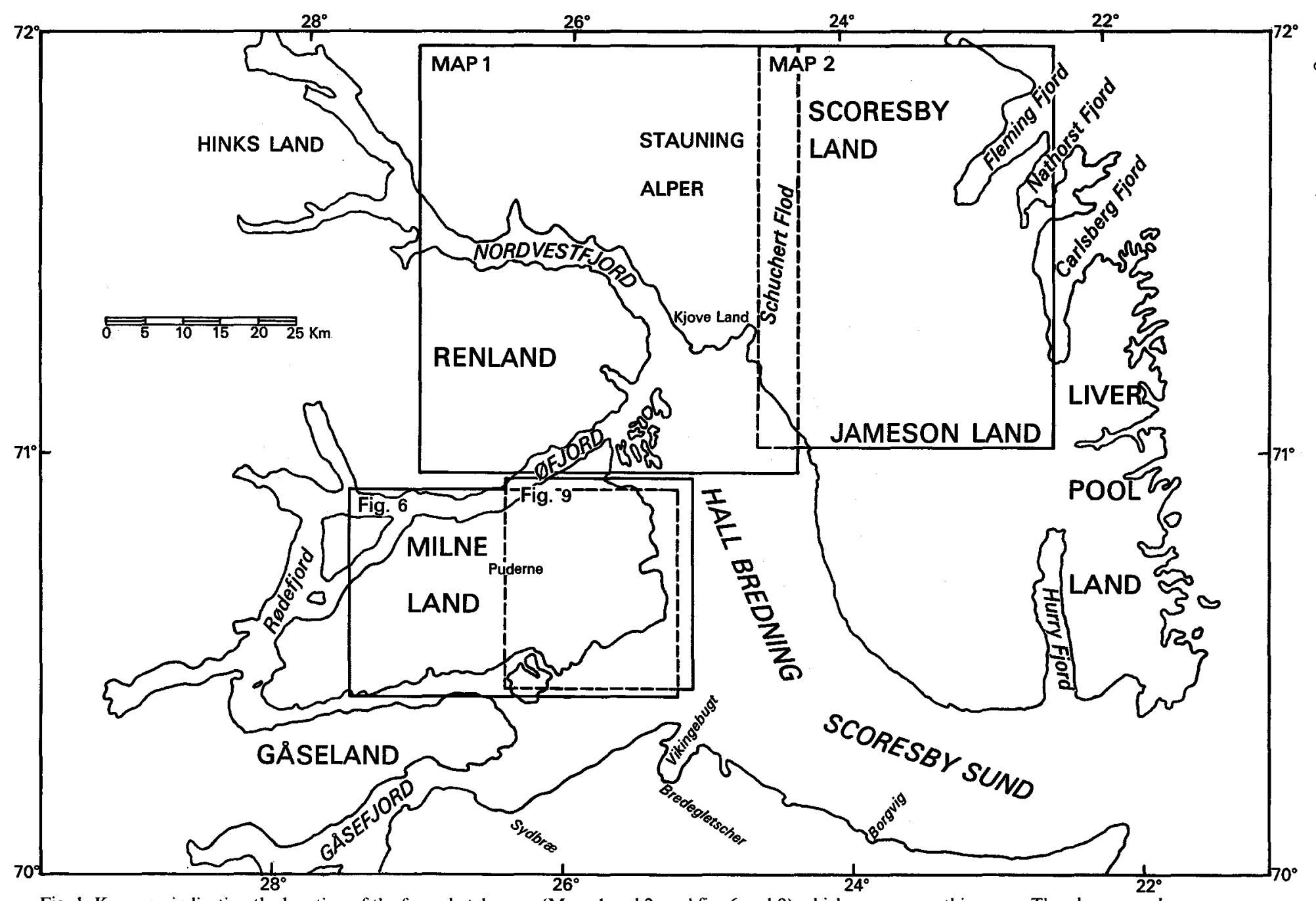

Fig. 1. Key map indicating the location of the four sketch maps (Maps 1 and 2, and figs 6 and 9) which accompany this paper. They key map also serves as a general geographical reference map for all four articles in the report. 


\section{Renland and southern Stauning Alper}

Previous and present investigations

Brief investigations in Nordvestfjord have been reported on by Backlund (1955) and Henriksen \& Watt (1968). The north part of Frederiksdal and the south side of Furesø have been investigated by Zweifel (1959) and the northern Stauning Alper have been described by Haller (1958).

A preliminary report of the region around inner Nordvestfjord adjoining the region with which this report is concerned, was presented by Henriksen \& Higgins (1969). An old pre-Caledonian gneissic basement was distinguished and two younger cover sequences of supracrustal rocks. The Charcot Land supracrustal sequence, comprising a belt of basic metavolcanics, calcareous, semipelitic and quartzitic rocks, is influenced by a northwards increasing metamorphism varying from greenschist to amphibolite facies. The Krummedal supracrustal sequence, several thousand metres thick, comprises siliceous gneisses, red-brown micaschists and quartzites metamorphosed mainly under almandine-amphibolite facies conditions. A major overthrust separates the two supracrustal sequences and their relative ages remain to be fully clarified. However, while the Krummedal sequence has been provisionally equated with the lower part of the Caledonian geosynclinal sequence, the Charcot Land sequence may be of greater age.

As it is traced eastwards the Krummedal sequence becomes intensely migmatised and there is a transition into the migmatites and gneisses around the outer half of Nordvestfjord.

A geological account of the Bjørneøer, situated south of the mouth of Nordvestfjord (map 1) and mapped during the 1968 Scoresby Sund Expedition, has been presented by Kalsbeek (1969). Kalsbeek distinguishes metasedimentary rocks, migmatites, three types of granites, diorites and several generations of dykes. His interpretations are in general accordance with those presented in this report.

In the areas north and south of the outer half of Nordvestfjord mapped during 1969, distinction may be made between Caledonian syn-kinematic and late-kinematic rocks and Caledonian post-kinematic intrusions. The syn-kinematic rocks include schists, gneisses, migmatites, migmatite granites and augen granites, whose deformation was succeeded by the late-kinematic emplacement of dioritic and granitic rocks and a late phase of migmatisation. Post-kinematic intrusions are almost restricted to the Stauning Alper region.

The marble-amphibolite-gneiss series

Around the northern part of Frederiksdal, in the north-west corner of the region mapped (map 1), a series of paragneisses, marbles, amphibolites and occasional quartzites may be distinguished. The amphibolites may be several hundred metres 
thick, the marbles while conspicuous are usually thinner; the paragneisses are very well banded, biotite-bearing and grey in colour.

Lithologically this suite of rocks bears comparison with the more highly metamorphosed and gneissified representatives of the Charcot Land supracrustal sequence as seen in the innermost part of Nordvestfjord. It is likely that the sequences are equivalent, although ice cover prevents direct correlation between the two areas.

Underlying this distinctive series in the Frederiksdal area may be found grey veined to banded gneisses with abundant thin conformable bands, schlieren, boudins and lenses of amphibolite, and discordant amphibolite dykes. In contrast to the overlying sequence these rocks exhibit signs of intense plastic deformation. In northern Frederiksdal both rock sequences have been folded together in major tight to isoclinal structures.

The lower sequence of gneisses is similar in character and appearance to the basement gneisses described from around Flyverfjord (Henriksen \& Higgins, 1969).

Krummedal supracrustal sequence schists and gneisses

The northward continuation of the pelitic and siliceous gneisses and schists of the T-sø area are found on the highest part of the mainly ice-covered plateau east and north-east of Frederiksdal. The non-migmatitic red-brown banded micaschists and quartzites here correspond in type to those seen in the upper Krummedal sequence of the type area, except that they also include a few thin bands and lenses of basic, and even ultrabasic rocks.

Between the non-migmatised Krummedal supracrustal rocks and the migmatites to the east occurs a transition zone comprising generally rusty-brown garnet-biotite gneisses with quartzite bands, and a number of less transformed bands of brown schistose micaceous gneiss. Leucocratic garnet-biotite granitic rocks also occur as conformable bands and exhibit both replacive and intrusive relationships to the gneisses; they presumably correspond to the neosome phase of the migmatites.

On both sides of Nordvestfjord south and west of Nordbugt occurs a zone of quartzites and highly siliceous gneisses which separates migmatitic rocks to the east from less migmatised rocks to the west. The quartzitic rocks are little affected by the migmatisation, and to some extent appear to have protected the rocks to the west from its effects.

The zone of quartzites and siliceous gneisses may be traced for some distance as a continuous unit, and is more than a $1000 \mathrm{~m}$ thick. This zone overlies rusty brown gneisses corresponding to the Krummedal sequence of the inner Nordvestfjord region, and probably represents a higher stratigraphical niveau or a lateral facies variation. 


\section{Migmatites}

The mapped region east of a north-south line through Nordbugt is dominated by migmatitic rocks in which the proportion of neosome component varies. The neosome usually comprises fine- to medium-grained garnet-biotite granitic material. In slightly migmatised rocks the neosome is found as thin conformable quartzo-feldspathic veins and schlieren. In more transformed rocks the neosome proportion may reach 90 per cent and the remnant lenses and partly digested blocks of palaeosome appear scattered and rotated suggesting that the neosome was highly mobile during deformation. Such rocks, which have a homogeneous and granitic appearence viewed from a distance of 50 to $100 \mathrm{~m}$, were given during mapping the fieldterm "migmatite granite". All transitions from slightly migmatised rocks to migmatite granites have been recorded.

Migmatitic rocks occur in a north-south trending zone about 60 to $80 \mathrm{~km}$ in width. The intensity of migmatisation varies across the zone and less strongly migmatised rocks occur at the east and west borders. In the central, highly migmatised part of the zone extensive areas, from 5 to $25 \mathrm{~km}$ across, may be classified as migmatite granites. The migmatite granites are not evenly distributed, and similar rocks have also been seen as conformable sheets with diffuse boundaries in the generally less migmatised border zones.

The gneissic rocks forming the border zones of the migmatite region exhibit a very pronounced banding clearly discernable at a distance of several kilometres. More homogeneous migmatitic rocks may also exhibit a banding at comparable distances which is not visible on a mesoscopic scale in outcrops; the megascopic banding always conforms to the general structure of the region and would appear to be an original lithological feature not completely masked by homogenisation processes.

The most abundant rocks in the palaeosome are banded quartzitic rocks and garnet-biotite gneisses. A zone mainly of quartzite has survived migmatisation on both sides of the outermost part of Nordvestfjord, but otherwise the only original layers encountered are marbles. The marble bands may be from 5 to $400 \mathrm{~m}$ in thickness, but often vary in thickness along their length and are rarely traceable individually for more than a few kilometres. However, a zone of migmatites including marble bands may be traced for considerable distances which suggests that they were probably a feature of a certain level in the original sedimentary pile. Amphibolitic rocks are almost unknown in the palaeosome.

The transition from non-migmatised Krummedal supracrustal rocks into slightly migmatised and then highly migmatised gneisses appears to be continuous. This, and the nature of the rock types preserved in the palaeosome, suggests that the entire migmatite region was probably formed by a migmatisation of Krummedal supracrustal sediments. There is no evidence for the existence of areas of reworked basement rocks. However, it must be mentioned that the considerable proportion of granitic neosome cannot readily be explained solely by local anatexis of an original supracrustal sequence. 
Augen granites

Thick medium-grained augen granite sheets are common in the south-western half of the migmatite and gneiss region. They are foliated, leucocratic garnet-biotite rocks with oriented microcline augen up to several centimetres in length. Parts of some of the sheets lack the characteristic augen and are very homogeneous, and other parts of the sheets have a very gneissic appearance.

The augen granites occur usually as concordant sheets 200 to $500 \mathrm{~m}$, rarely 1000 $\mathrm{m}$, in thickness. The sheets in many places cut the banding in the surrounding gneisses and migmatites at a small angle, and also contain scattered inclusions of the country rocks. While essentially intrusive bodies the age relations between their emplacement and the formation of the granitic neosome of the migmatites is not completely known, although it is apparent that some of the neosome is younger than the augen granites.

From west to east the first sheets are encountered in the weakly migmatised pelitic gneisses west of Nordbugt. Further east they become more common and extensive; single sheets in north-east Renland may be traced for 10 to $20 \mathrm{~km}$. They are most abundant in south-west Renland where they are interlayered with rusty brown Krummedal sequence gneisses. In south-eastern Renland, however, they are lacking within a basin structure bounded by an extensive sheet-like body of dioritic rocks and mafic granites (described below), and they have not been recorded in the northern part of the migmatite region north of Nordvestfjord.

Dioritic rocks and mafic granites s. 1 .

An extensive intrusive dioritic sheet up to $500 \mathrm{~m}$ thick occurs in south-eastern Renland where it outlines part of a basin-shaped structure. In the southern part of the outcrop the dioritic rocks form a distinct boundary between granitised migmatites and granites within the structure and augen granites and rusty gneisses outside and south-west of the basin.

Within the basin structure defined by the major sheet there occur a number of small dioritic bodies as sheets, dykes or irregular shaped forms. Small bodies of similar type also occur in the region north of Nordvestfjord.

The dioritic rocks are usually medium-grained dark greenish-brown rocks, often preserving original magmatic textures without preferred mineral orientation. In composition they vary from diorites to quartz diorites, to quartz monzonitic and adamellitic types rich in mafics. Kalsbeek (1969) has described a number of dioritic intrusions on the Bjørneøer as containing as dark minerals biotite, hypersthene, clinopyroxene and brownish-green hornblende in order of abundance. The plagioclase is generally a calcic andesine.

The larger dioritic bodies are not usually migmatised except sometimes in their marginal zones, but may be cut by granitic veins and pegmatites oriented mainly perpendicular to the boundaries of the dioritic rocks. Smaller bodies affected by 
migmatisation lose their magmatic characteristics, recrystallise and develop a foliation.

A metapyroxenite body $4 \mathrm{~km}$ in diameter and a few smaller amphibolitic bodies found in the eastern part of the Stauning Alper may be co-genetic with the dioritic rocks, but no detailed information is at present available.

Grey-pink granites

Abundant flat-lying sheets of grey-pink granite occur in the higher mountains of south-eastern Renland within the basin structure defined by the major dioritic body. The granites are generally foliated, but can be homogeneous, and contain up to 10 per cent of conformable lenses and inclusions of dark grey-brown gneiss. The sheets vary in thickness in an irregular manner and may be from 5 to $1000 \mathrm{~m}$ thick.

The granite sheets are less common towards the outer part of the basin structure where they are interlayered with the migmatised gneisses into which they were injected.

Along the coast of Øfjord grey-pink granite material forms the youngest neosome of a migmatite in which the palaeosome comprises an earlier formed migmatite and granitised diorite. In its turn the earlier migmatite contains inclusions of quartzites and mica gneisses probably originally part of the Krummedal sequence.

\section{Late-kinematic dykes}

Leucocratic and melanocratic dykes, generally less than a metre but occasionally several metres wide, are common throughout the region. Their trends are often irregular, and impersistent lithological characteristics add to the difficulties of interpreting their relationships to each other. Within the area of a single outcrop 6 to 8 generations of dykes and pegmatites have been distinguished, all later than the intensely deformed migmatites which they cut. However, it has not yet been possible to establish a pattern of dyke intrusion on a regional basis.

The dykes discussed in this category represent a late-kinematic event, probably the last manifestation of regional migmatisation and granitisation. In composition they vary from leucocratic granite types to quartz dioritic types, which are very common, to melanocratic and basic types.

\section{Metamorphism}

In the region west of that shown on map 1 the schists and gneisses of the Krummedal supracrustals exhibit the paragenesis kyanite-garnet-biotite, indicative of a medium grade of the almandine-amphibolite facies of high pressure (Barrow) type. In some rocks kyanite co-exists with sillimanite indicating conditions corresponding to the boundary area between the kyanite and sillimanite zone of the Scottish Dalradian.

As they are traced eastwards towards the migmatite region kyanite is restricted to the schists and the general paragenesis in the gneissic transition zone is silliman- 
ite-garnet-biotite. Further east, in the migmatite region, cordierite appears in assemblages with sillimanite and garnet. In the central part of the migmatite region where the migmatite granites abound cordierite occurs in small amounts, but widely distributed, in both palaeosome and neosome. The parageneses here are indicative of medium amphibolite facies conditions of low pressure type.

The change from high pressure conditions in the western supracrustals to low pressure conditions in the migmatites can be traced along Nordvestfjord over a 40$60 \mathrm{~km}$ stretch.

Around the Bjørneøer in the south-east corner of the region cordierite occurs in the migmatites and, sometimes with sillimanite, in metasedimentary relics. Biotitehypersthene-diopside-brownish green hornblende-Ca-rich plagioclase-quartz assemblages have been noted in Ca-rich gneisses and biotite-hypersthene-clinopyroxene-brownigh green hornblende-Ca plagioclase \pm quartz in dioritic rocks (Kalsbeek, 1969). Both pyroxenes have also been found in the migmatites of the area, and Kalsbeek has concluded that the rocks were metamorphosed under conditions of the granulite facies (hornblende granulite subfacies).

The west-to-east metamorphic variations across the region are suggestive of a general decrease in pressure eastwards and a slightly increased temperature in the crystalline complex around the Bjørneøer.

\section{Structures}

The marble-amphibolite-gneiss series in the Frederiksdal area exhibits major tight to isoclinal folds generally with E-W trending fold axes. The underlying, presumed basement, grieisses are also distorted by the same structures but exhibit in addition an earlier plastic style of folding. These presumed basement rocks appear also in some sections to have been tectonically emplaced into the rocks above as thrust wedges.

In most of the region formed from Krummedal supracrustal rocks the dominant structures are extensive tight to isoclinal recumbent folds with subhorizontal axial planes; the fold limbs may have overlaps of the order of $5 \mathrm{~km}$. Towards the west the attitude of the folds steepens and they are generally overturned westwards. Much of the region is dominated by flat-lying banding. The recumbent folds are best seen in Renland where they deform thick sheets of augen granite which are good marker horizons. The dioritic sheet in south-east Renland post-dates the recumbent folds, as also do the grey-pink granites.

On a mesoscopic scale folds are common in the gneisses, but their relationships to the major structures remain to be clarified.

In south-west Renland open north-south folds deform the recumbent structures; they have steep axial planes and gently plunging axes. Major open structures with the same characteristics also occur in the Stauning Alper, but here they are more widely spaced with tens of kilometres between each of the main folds.

On the Bjørneøer open structures defined by the foliation and the orientation of 
schlieren in migmatites are suggested by Kalsbeek (1969) to be late- or post-migmatitic. However, the relationships between these structures and those found in the remainder of the region have not yet been demonstrated.

Post-kinematic granites s. 1 .

Granitic intrusions of late- to post-kinematic age are common in the northern part of the region. They are almost confined to the Stauning Alper, only a few being found on the Bjørneøer and in north-east Milne Land.

The intrusions show considerable variation in size from sheets and dykes only a few metres thick to irregular bodies outcropping over areas of 8 by $20 \mathrm{~km}$. Their boundaries to the surrounding migmatites are usually sharp, but transgressive relationships have been recorded. No marked contact metamorphic effects have been noted.

The composition of the intrusions varies from body to body, and also varies significantly in some cases within a single pluton. Porphyritic biotite granites are the most widespread, and form the major part of the larger bodies. Fine-grained homogeneous biotite granites or granodiorites are also important, and leucocratic biotite-muscovite granites may represent a late variation. Some of the larger granite bodies have central zones, in some cases several square kilometres in outcrop area, of hornblende syenite. The syenites, and some of the acidic intrusions, may contain sphalerite.

Aplites and muscovite-rich pegmatites post-dating the granites are abundant wherever the granites are found, and lamprophyric dykes have been noted in a few places.

\section{Faults}

The most prominent faults are those which make up the post-Carboniferous boundary fault zone which follows the east side of the Stauning Alper and separates crystalline rocks to the west from the Upper Palaeozoic and Mesozoic rocks of the Jameson Land basin to the east. Within the crystalline complex a system of mylonites occurs parallel to the boundary faults.

North-south trending faults are most prominent in south-east Renland, but are also recorded in other parts of the region. In Renland a set of normal faults with downthrow to the east have an estimated total downthrow of 1000 to $1500 \mathrm{~m}$.

Basic dykes and volcanic breccias

Scattered basic dykes of presumed Tertiary age occur around parts of outer Nordvestfjord, but are less common than they are in inner Nordvestfjord (Henriksen \& Higgins, 1969). Basic sills, also of presumed Tertiary age, are found locally in the north-east corner of the region near the border fault of the crystalline complex, but are more common in the adjacent Palaeozoic and Mesozoic sediments. 
In the north-east part of the crystalline complex there occur three small igneous bodies of unusual composition. They appear to have the characteristics of volcanic breccias comprising numerous rock fragments of various composition in a mainly basic matrix. Large pyroxene crystals up to $10 \mathrm{~cm}$ in length were observed in one of them. A basic porphyritic rock fragment found in one of the bodies, identical in appearance to nearby presumed Tertiary sills, makes it likely that the bodies are also Tertiary in age, as does their proximity to the known Tertiary complex of the Werner Bjerge (Bearth, 1959).

\section{Liverpool Land}

Previous investigations

Kranck (1935) has described the southern half of Liverpool Land and presented a reconnaissance map of the region. He distinguished several migmatite gneiss units, granodioritic and granitic synorogenic intrusions and post-kinematic granites. Eclogitic rocks in one of the gneiss units have been described by Sahlstein (1935). A thin sequence of non-metamorphosed sediments resting on crystalline rocks on the east coast of the northern part of Hurry Fjord were attributed a lower or middle Palaeozoic age by Kranck, but were considered by Bütler (1957) to be Eotriassic.

Present investigations

The mapping of south-east Liverpool Land was begun by GGU in 1969 and will be continued in 1971. The investigations are incomplete and are therefore only given brief mention below. The following geological divisions have so far been established:

a) Basic dykes and sills (youngest).

b) Non-metamorphosed sediments.

c) Hurry Fjord granite complex.

d) Gneisses (oldest).

\section{Gneisses}

In south-west Liverpool Land five lithological units have been distinguished in the flat-lying gneiss sequence between sea-level and about $1000 \mathrm{~m}$ altitude. These include various gneisses of slightly different characteristics, the lowest unit containing inclusions of eclogitic rocks, and a marble unit from 0 to $200 \mathrm{~m}$ thick. Banded to veined gneisses north-east of the Hurry Fjord granite also contain a few marble horizons. 
by 12 kilometres. The marginal zone may contain abundant country rock xenoliths. The contacts are normally sharp or follow fault lines, but gradational relationships with the gneisses have been reported.

Small diorite bodies occur in the south-east part of the granite, clearly post-dating the main body but perhaps genetically related to it.

The Hurry Fjord granite complex is regarded as a post-kinematic intrusion of probable Caledonian age.

Non-metamorphosed sediments

On the east side of the northern part of Hurry Fjord a continuous series of nonmetamorphosed conglomerates, arkoses, quartzites, flags, siltstones and mudstones abut, mainly in fault contact, on the Hurry Fjord granite. The sequence dips gently westwards. Plant remains have been found locally; the age of the sequence is probably Upper Palaeozoic or Lower Mesozoic.

Basic dykes and sills

Lamprophyre dykes with euhedral biotite phenocrysts, dolerite dykes and sheets, and feldsparphyric sills post-date all the rock types described above. The basaltic rocks are probably of Tertiary age.

\section{Concluding remarks}

The marble-amphibolite-gneiss series exposed in the north-west of the region mapped around Frederiksdal forms a distinctive sequence which probably can be correlated with the Charcot Land supracrustal sequence. The gneisses and enclosed discordant amphibolites on which this series rests may be compared with the basement rocks exposed in the Flyverfjord region (Henriksen \& Higgins, 1969).

The gneisses and migmatites comprising the major part of the crystalline complex around outer Nordvestfjord appear to be derived from rocks of the Krummedal supracrustal sequence. The homogeneous quartzitic rocks are apparently not represented in the inner Nordvestfjord region and may represent a higher stratigraphical niveau of the supracrustal sequence, or a lateral facies variation. The Krummedal supracrustals are of similar lithology and are probably equivalents of the Alpefjord Formation which comprises the lower part of the Caledonian geosynclinal succession (Fränk1, 1951, 1953). The type locality of the Alpefjord Formation lies just north of the region with which this report is concerned.

Correlation of Krummedal supracrustal rocks with those of the Alpefjord Formation implies that the gneisses and migmatites of the Stauning Alper and Renland were formed principally by gneissification and migmatisation of Caledonian geosynclinal deposits.

The age of the Charcot Land supracrustal sequence is not established, but need 
not necessarily comprise Caledonian geosynclinal deposits as was presumed by Wenk (1961) and Vogt (1965); both use the term "marble-chlorite-phyllite series" for what is here called the Charcot Land supracrustal sequence. In the writers' view it is equally likely that they are a pre-Caledonian sequence reworked by Caledonian events. It is hoped that radiometric age determinations will clarify their age relations.

The plutonic development of the Nordvestfjord region spans synkinematic through late-kinematic to post-kinematic events of the Caledonian orogeny. Whereas evidence of synkinematic events can be seen throughout the region, late-kinematic events mainly affected Renland and post-kinematic events were mainly confined to the Stauning Alper.

The synkinematic neosome granites and augen granites are complex types comprising several phases which grade into each other. On Renland the late-kinematic rocks can clearly be distinguished as they post-date the recumbent fold structures disturbing the synkinematic rocks. The youngest late-kinematic rocks are granite types which form intrusive sheets and also the neosome phase of late migmatites. Distinction of a late-kinematic phase is less clear in the Stauning Alper, but this phase may be represented by some homogeneous granitic bodies. The post-kinematic granites of the Stauning Alper, which sometimes have central syenitic zones, are mainly clearly intrusive, but in some cases there are gradations between intrusive granites and partly metasomatic granites. The overall impression is indicative of continuous plutonic activity spanning the late- to post-kinematic development of the region.

\section{References}

[Backlund, H. G.], 1955: Helge Backlund's travels. In Koch, L. Report on the expedition to central East Greenland 1926-39. Conducted by Lauge Koch. Part II. Meddr Grenland 143, 2, 303-361.

Bearth, P. 1959: On the alkali massif of the Werner Bjerge in East Greenland. Meddr. Gronland 153, 4, $63 \mathrm{pp}$.

Bütler, H. 1957: Beobachtungen an der Haupbruchzone der Küste von Zentral-Ostgrönland. Meddr Grenland 160, 1, $79 \mathrm{pp}$.

Fränkl, E. 1951: Die untere Eleonore Bay Formation in Alpefjord. Meddr Grenland 151, 6, 15 pp.

Fränkl, E. 1953: Die Geologische Karte von Nord-Scoresby Land (NE-Grønland). Meddr Grenland 113, $6,56 \mathrm{pp}$.

Haller, J. 1958: Der »Zentrale Metamorphe Komplex، von NE-Grönland. Teil II. Die Geologische Karte der Stauning Alper und des Forsblads Fjordes. Meddr Grenland 154, 3, 153 pp.

Henriksen, N. \& Higgins, A. K. 1969: Preliminary results of mapping in the crystalline complex around Nordvestfjord, Scoresby Sund, East Greenland, Rapp. Grenlands geol. Unders. 21, 3-20.

Henriksen, N. \& Watt, W. S. 1968: Geological reconnaissance of the Scoresbysund Fjord Complex. Rapp. Grenlands geol. Unders. 15, 72-77.

Kalsbeek, F., 1969: Preliminary report on the geology of Bjerneeer, Scoresby Sund. Rapp. Gronlands geol. Unders. 26, 33 pp.

Kranck, E. H. 1935: On the crystalline complex of Liverpool Land. Meddr Grenland 95, 7, 122 pp.

Sahlstein, Th. G. 1935: Petrographie der Eklogiteinschlüsse in den Gneisen des südwestlichen Liverpool-Landes in Ost-Grönland. Meddr Gronland 95, 5, 43 pp. 
Vogt, P. 1965: Zur Geologie von Südwest Hinks Land (Ostgrönland 71 30' N). Meddr Gronland 154, 5 , $24 \mathrm{pp}$.

Wenk, E. 1961: On the crystalline basement and the basal part of the pre-Cambrian Eleonore Bay Group in the southwestern part of Scoresby Sund. Meddr Grønland 168, 1, $54 \mathrm{pp}$.

Zweifel, H. 1959: Geologie und Petrographie von Nathorsts Land (NE-Grönland). Meddr Gronland 160. 3, 94 pp.

\title{
PRELIMINARY RESULTS OF MAPPING IN THE PALAEO- ZOIC AND MESOZOIC SEDIMENTS OF SCORESBY LAND AND JAMESON LAND
}

\author{
R. G. Bromley, J. Bruun-Petersen, and K. Perch-Nielsen
}

\section{Introduction}

In the 1969 summer season mapping was concentrated in those areas of southern Scoresby Land and northern Jameson Land which had not been visited in 1968 (see Birkelund \& Perch-Nielsen, 1969). Mapping was extended westward to the main fault of the post-Caledonian sedimentary basin against the Stauning Alper and to the south as far as $71^{\circ} 10^{\prime}$.

The field work was carried out by R. G. Bromley, L. and C. Malmros, K. PerchNielsen, J. Bruun-Petersen, C. Heinberg, and E. Hjelmar. The preliminary results of the mapping are given in this report together with a geological map at a scale of $1: 300000$, compiled from the existing maps (Aellen, in press; Bearth \& Wenk, 1959; Callomon, in press; Trümpy \& Grasmück; 1969) and our own observations. Special attention was given to trace fossils by. R. G. Bromley and the heavy mineral assemblages in the Mesozoic sediments by J. Bruun-Petersen.

\section{Palaeozoic}

Devonian

Outcrops of probably Upper Devonian age were found to underlie the Upper Permian basal conglomerate and reefy limestone in and on both sides of the river falling to the head of Nathorst Fjord. They consist of sandstones and shales with a few conglomerate beds and dip steeply westward.

(?) Carboniferous and Lower Permian

On the west side of the basin Palaeozoic sediments are down-faulted against the Caledonian crystalline of the Stauning Alper by a system of faults with a predomi- 